\title{
TNF $\alpha$ Decreases Gluconeogenesis in Hepatocytes Isolated from 10-Day-Old Rats
}

\author{
MASAKATSU GOTO, TOYOKAZU YOSHIOKA, TADEJ BATTELINO, \\ THYYAR RAVINDRANATH, AND W. PATRICK ZELLER \\ Departments of Pediatrics [M.G., T.Y., T.B., TR., W.P.Z.] and Physiology [W.P.Z.], The Ronald \\ McDonald Children's Hospital at Loyola, Loyola University of Chicago, Maywood, Illinois 60153, U.S.A.; \\ e-mail:masakatsu@ameritech.net
}

\begin{abstract}
ABST
Gluconeogenesis decreases during septic shock, but its mech-
anism is not well known. Tumor necrosis factor alpha (TNF- $\alpha$ ),
which is a key cytokine in septic shock, can increase GLUT1
gene expression and glucose uptake in muscles and fatty tissues.
TNF- $\alpha$ does not alter the metabolism of hepatocytes in which
GLUT2 is the predominant glucose transporter. However,
GLUT1 is the predominant glucose transporter in hepatocytes of
10-d-old rats. Thus, we hypothesized that TNF- $\alpha$ might increase
glucose uptake and glycolysis in those cells, and decrease glu-
coneogenesis. In the present study, hepatocytes isolated from
10-d-old rats were incubated with TNF- $\alpha$ at the concentrations of
0, $0.98,9.8,98$, and 980 ng/mL to evaluate TNF- $\alpha$ effects on
gluconeogenesis and glucose uptake. TNF- $\alpha$ increased glucose
uptake $(41.1 \pm 8$ to $114 \pm 21.4 \mu$ mol/10
tration of 980 ng/mL of TNF- $\alpha$ ) in a dose-dependent manner, and
decreased gluconeogenesis $(98.2 \pm 8.2$ to $1.1 \pm 3.2 \mu$ mol/10
\end{abstract}
Gram-negative septic shock in the newborn remains a major medical problem because of its high incidence and mortality. Endotoxin (lipopolysaccharide: LPS), a component of outer cell membrane of Gram-negative bacteria, plays an important role in Gram-negative septic shock. Whereas the $\mathrm{LD}_{90}$ of Salmonella enteritidis LPS is $0.1 \mathrm{mg} / \mathrm{kg}$ in 10 -d-old rats, it is $35 \mathrm{mg} / \mathrm{kg}$ in adult rats (1), indicating that the newborn is more sensitive to LPS than the adult. The high sensitivity to LPS in the newborn is ascribed to immature pituitary-adrenal function (2), but this alone cannot fully explain the mechanism of the high sensitivity.

Glucose dyshomeostasis such as hyperglycemia and hypoglycemia is a common sign in Gram-negative septic shock (1, 3-5). Because severe hypoglycemia may result in severe neurologic sequelae in the newborn, hypoglycemia during shock is a critical problem. During septic shock, glycolysis is increased and gluconeogenesis is decreased in the liver $(4,5)$. The

Received August 23, 1999; accepted August 1, 2000.

Correspondence: Masakatsu Goto, M.D., Ph.D., 704 Marion, Oak Park, IL 60302, U.S.A.

Supported by the Research Education Fund of the Department of Pediatrics of Loyola University. cells at the concentration of $980 \mathrm{ng} / \mathrm{mL}$ of TNF- $\alpha$ ) in a dosedependent manner. The decrease of glucokinase mRNA and GLUT1 mRNA abundance correlated with glucose uptake $(r=$ 0.988 and 0.997 , respectively), and the decrease of phosphoenolpyruvate carboxykinase mRNA abundance correlated with the decrease of gluconeogenesis $(r=0.972)$. The decrease of gluconeogenesis by TNF- $\alpha$ correlated with the increase of glucose uptake $(r=-0.988)$. We concluded that TNF- $\alpha$ reciprocally suppressed gluconeogenesis in hepatocytes isolated from 10-dold rats. (Pediatr Res 49: 552-557, 2001)
Abbreviations
PEPCK, phosphoenolpyruvate carboxykinase
GK, glucokinase
TNF- $\boldsymbol{\alpha}$, tumor necrosis factor alpha
2DG, 2-deoxy-D-glucose

activity and mRNA abundance of PEPCK, a key gluconeogenic enzyme, are decreased during septic shock (5-7). Because gluconeogenesis is necessary to maintain plasma glucose concentration in the newborn, even at the postprandial state (8), decrease of gluconeogenesis may easily lead to hypoglycemia. Because plasma concentration of insulin, which is a major glucoregulatory hormone and can inhibit gluconeogenesis, increases during septic shock in the adult $(1,3,9)$, hyperinsulinemia is postulated to be responsible for the hypoglycemia in adults. In contrast to the adult, plasma insulin concentration does not increase in the newborn $(1,5)$. Thus, insulin does not seem to be responsible for the decrease of gluconeogenesis and plasma glucose concentration in the newborn. When hepatocytes are isolated from adult animals and incubated with LPS, metabolism such as protein synthesis is not altered (10). Our previous study showed that LPS infusion does not alter glucose production in livers isolated from 10-d-old rats when Kupffer cell function is decreased (11), suggesting that LPS by itself does not alter hepatocyte glucoregulation in the newborn.

TNF- $\alpha$ is thought to be a key mediator in septic shock. TNF- $\alpha$ increases in the plasma during septic shock (12), and 
TNF- $\alpha$ injection induces hypotension, metabolic alteration, and death in animals (13). TNF- $\alpha$ injection into adult mice decreases gluconeogenesis, PEPCK gene expression, and plasma glucose concentration $(14,15)$. TNF- $\alpha$ injection into 10-d-old rats also induces hypoglycemia, decreasing PEPCK gene expression (16). These results suggest that TNF- $\alpha$ decreases gluconeogenesis in both newborn and adult animals. In hepatocytes isolated from adult rats, however, gluconeogenesis is not altered after a short incubation with TNF- $\alpha$ (17). TNF- $\alpha$ effects on glucose metabolism in hepatocytes isolated from newborns are not well known.

Glucose transporters, a family of proteins, transport glucose across cell membranes. Glucose transporters are developmentally regulated (18). GLUT1, a ubiquitous glucose transporter, is predominant in the fetus and newborn, including livers of 10-d-old rats, and transports glucose primarily into cells (18, 19). GLUT2, the liver-specific glucose transporter, is predominant in adult hepatocytes (18) and transports glucose bidirectionally across cell membranes (18). Therefore, hepatocytes in the newborn are different from those in the adult.

TNF- $\alpha$ increases noninsulin-mediated glucose uptake and GLUT1 gene expression $(20,21)$. Because GLUT1 is an insulin-insensitive glucose transporter (18), GLUT1 seems to play an important role in TNF- $\alpha$-induced glucose uptake. TNF- $\alpha$ injection increases tissue glucose uptake and GLUT1 gene expression in 10-d-old rats in which GLUT1 is predominant (16). TNF- $\alpha$ decreases gene expression of gluconeogenic enzymes in hepatoma cell lines in which GLUT1 is predominant (14). TNF- $\alpha$ decreases gluconeogenesis in hepatocytes isolated from adult rats when the hepatocytes are cultured for $5 \mathrm{~d}$ before TNF $\alpha$ treatment (22). Because prolonged cell culture or glucose deprivation induces GLUT1 predominance $(23,24)$, TNF- $\alpha$-induced alteration of the hepatocyte glucoregulation may be a result of the increase of GLUT1. Thus, we hypothesize that, in hepatocytes isolated from the newborn, TNF- $\alpha$ increases glucose uptake and glycolysis and reciprocally suppresses gluconeogenesis.

In the present study, hepatocytes isolated from 10-d-old rats were used to evaluate whether LPS or TNF- $\alpha$ by itself decreases gluconeogenesis. We have used 10-d-old rats as an animal model of the newborn $(1,5)$. To compare TNF- $\alpha$ effects on hepatocyte gluconeogenesis between the newborn and the adult, hepatocytes isolated from adult rats were also used.

\section{MATERIALS AND METHODS}

Chemicals. Recombinant murine TNF- $\alpha$ was a gift from Genentech Inc. (San Francisco, CA, U.S.A.). $\left[3-{ }^{14} \mathrm{C}\right]$-lactate and $\left[\mathrm{U}_{-}{ }^{14} \mathrm{C}\right]-2 \mathrm{DG}$ were purchased from Amersham Life Science (Arlington Heights, IL, U.S.A.). Collagenase was purchased from Worthington Biochemical Corp. (Freehold, NJ, U.S.A.), and $\mathrm{CO}_{2}$-independent media and RPMI1640 were purchased from GIBCO BRL (Grand Island, NY, U.S.A.). Reagents were purchased from Sigma Chemical Co. (St. Louis, MO, U.S.A.), unless otherwise specified.

Animals. Pregnant Sprague Dawley rats (Harlan, Indianapolis, IN, U.S.A.) were purchased on gestational d 12. The rats were housed individually in our animal care facility with controlled room temperature, humidity, and light (0700-1700 $\mathrm{h}$ light on), and were fed water and rat chow (Allied Mills, Madison, WI, U.S.A.) ad libitum. Newborns were kept with their dams until experiments were performed. Ten-day-old rats and nonpregnant, nonlactating adult female rats were used in the experiments. The study was approved by the Institutional Review of Animal Care and Use Committee.

Hepatocyte isolation. Hepatocytes were isolated with a modified method of Harbrecht et al. (25) as follows: Portal vein cannulation was performed under pentobarbital $(35 \mathrm{mg} / \mathrm{kg}$ i.p.; Butler Inc., Columbus, OH, U.S.A.) anesthesia. The liver was perfused ex vivo with $\mathrm{PBS}$ for $5 \mathrm{~min}$ at $15 \mathrm{~cm} \mathrm{H}_{2} \mathrm{O}$, then digested with collagenase in $\mathrm{CO}_{2}$-independent media at $15 \mathrm{~cm}$ $\mathrm{H}_{2} \mathrm{O}$. Collagenase was infused at the concentration of $0.01 \%$ for $5 \mathrm{~min}$ in the $10-\mathrm{d}$-old rats, and at $0.2 \%$ for $7 \mathrm{~min}$ in the adults. Liver cells in $\mathrm{CO}_{2}$-independent media were dispersed by manual shaking, and filtered with $50-\mu \mathrm{m}$ nylon mesh (Spectrum, Laguna Hills, CA, U.S.A.). The filtered cell suspension was centrifuged at $490 \mathrm{rpm}(\times 50 \mathrm{~g})$ for $1 \mathrm{~min}$, and the supernatant was discarded. The pellet was resuspended in $\mathrm{CO}_{2}$-independent media, and the cell suspension was centrifuged at $490 \mathrm{rpm}$ for $1 \mathrm{~min}$. The supernatant was discarded. The cells in the pellet were considered hepatocytes. Hepatocytes were $>80 \%$ in those cells and trypan blue exclusion test revealed that cell viability was $>85 \%$ of hepatocytes.

Hepatocyte incubation. Hepatocyte incubation media was RPMI1640 supplemented with penicillin (100 unit $/ \mathrm{mL})$ and streptomycin $(0.1 \mathrm{mg} / \mathrm{mL})$. Hepatocytes $\left(10^{6}\right.$ cells $\left./ \mathrm{mL}\right)$ were incubated in $5 \% \mathrm{CO}_{2}$ at $37^{\circ} \mathrm{C}$. As neither cell viability was altered nor RNA degradation was induced for a 3-h incubation, hepatocytes were incubated for $3 \mathrm{~h}$.

Effects of endotoxin on glucose production of hepatocytes. Hepatocytes $\left(10^{6}\right.$ cells $\left./ \mathrm{mL}\right)$ from 10 -d-old rats were incubated with $10 \mathrm{mM}$ lactate, $1 \mathrm{mM}$ pyruvate, and Salmonella enteritidis LPS (Difco, Detroit, MI, U.S.A.) at the dose of $0,0.01$, or 0.1 $\mu \mathrm{g} / \mathrm{mL}$ in the incubation media for $3 \mathrm{~h}$. Glucose concentrations in the incubation media before and after hepatocyte incubation were measured using a YSI glucose analyzer (Yellow Springs Instruments, Yellow Springs, OH, U.S.A.). Glucose production was calculated from the difference in glucose concentrations of the incubation media before and after incubation. Data were obtained from 12 experiments.

Effects of TNF- $\alpha$ on gluconeogenesis. Hepatocytes isolated from 10-d-old rats were divided into five groups as follows: group 1 (noTNF $\alpha, n=12)$ : without TNF- $\alpha$; group 2 $(0.98 \mathrm{TNF}-\alpha, n=12): 0.98 \mathrm{ng} / \mathrm{mL}$ of $\mathrm{TNF}-\alpha$; group 3 (9.8TNF- $\alpha, n=10): 9.8 \mathrm{ng} / \mathrm{mL}$; group 4 (98TNF- $\alpha, n=12)$ : $98 \mathrm{ng} / \mathrm{mL}$ of TNF- $\alpha$; and group 5 (980TNF- $\alpha, n=12$ ): 980 $\mathrm{ng} / \mathrm{mL}$ of TNF- $\alpha$. Hepatocytes were incubated in the incubation media with $10 \mathrm{mM}$ of lactate, $1 \mathrm{mM}$ of pyruvate, $10 \mu \mathrm{Ci}$ $\left[3-{ }^{14} \mathrm{C}\right]$-lactate, and recombinant murine TNF- $\alpha$ at the doses mentioned above for $3 \mathrm{~h}$. Hepatocytes isolated from adult rats were also incubated in the incubation media with $10 \mathrm{mM}$ of lactate, $1 \mathrm{mM}$ of pyruvate, $10 \mu \mathrm{Ci}\left[3-{ }^{14} \mathrm{C}\right]-$ lactate, and recombinant murine TNF- $\alpha$ at the doses of $0,9.8$, or $980 \mathrm{ng} / \mathrm{mL}$ for $3 \mathrm{~h}$. Eight experiments were performed on hepatocytes from adult rats. Glucose from the incubation media was isolated using AG1-X8 formate resin column (Bio-Rad Laboratories, 
Hercules, CA, U.S.A.). Radioactivity of isolated glucose was counted using a liquid scintillation counter (Packard, Meriden, CT, U.S.A.). Lactate concentration was measured using a YSI lactate analyzer (Yellow Springs Instruments, Yellow Springs, OH, U.S.A.). Gluconeogenesis was calculated from radioactivity of glucose in incubation media and lactate concentration. To determine abundance of mRNA of GLUT1, GLUT2, and PEPCK, hepatocytes were harvested after the incubation.

Glucose uptake. Glucose uptake in isolated hepatocytes was measured with a modification of the method of Chen et al. (26). Hepatocytes isolated from 10-d-old rats were divided into three groups as follows: group $\mathrm{A}$ (noTNF $\alpha, n=5$ ): without TNF- $\alpha$; group B (9.8TNF- $\alpha, n=5): 9.8 \mathrm{ng} / \mathrm{mL}$ of TNF- $\alpha$; and group C (980TNF- $\alpha, n=5): 980 \mathrm{ng} / \mathrm{mL}$ of TNF- $\alpha$. Hepatocytes were incubated for $60 \mathrm{~min}$. The incubation media contained $1 \mu \mathrm{Ci}$ $\left[\mathrm{U}-{ }^{14} \mathrm{C}\right]-2 \mathrm{DG}(\approx 250 \mu \mathrm{Ci} / \mathrm{mM})$ and TNF- $\alpha$ at the doses mentioned above. Before incubation, $0.4 \mathrm{~mL}$ of cell suspension was taken to measure glucose concentration and to count radioactivity. Hepatocyte glucose uptake was measured as follows: The incubation media containing hepatocytes was centrifuged. The supernatant was used to measure glucose concentration and to count radioactivity. Hepatocytes were homogenized in 3 $\mathrm{mL}$ of $0.5 \mathrm{~N}$ perchloric acid and centrifuged. Two milliliters of supernatant was neutralized with $5 \mathrm{M} \mathrm{KOH}$, and centrifuged. Supernatant at the volume of $0.5 \mathrm{~mL}$ was used for the measurement of radioactivity of total 2DG (nonphosphorylated 2DG, phosphorylated glucose). Then, $0.5 \mathrm{~mL}$ of $5 \% \mathrm{ZnSO}_{2}$ was added to $1 \mathrm{~mL}$ of the supernatant, followed by $0.5 \mathrm{~mL}$ of $0.3 \mathrm{~N} \mathrm{Ba}(\mathrm{OH})_{2}$ to absorb phosphorylated 2DG. The mixture was centrifuged and the radioactivity in $1 \mathrm{~mL}$ of the supernatant was counted. Phosphorylated 2DG was calculated from total 2DG by subtracting nonphosphorylated 2DG. The incubation media was added to $300 \mu \mathrm{L}$ of $4 \mathrm{M}$ perchloric acid and neutralized with $300 \mathrm{~K}_{2} \mathrm{CO}_{3}$. After centrifugation, radioactivity of $30 \mu \mathrm{L}$ of the supernatant was counted. Glucose concentration of the incubation media was also measured. Hepatocyte glucose uptake was calculated as follows:

glucose uptake $=$ phosphorylated $2 \mathrm{DG}$ uptake of cells $/ \int_{0}^{60}$ $\left(2 \mathrm{DG}_{\text {supernatant }} / \mathrm{G}_{\text {supernatant }}\right) \mathrm{dt}$

Furthermore, to determine mRNA abundance of GK, hepatocytes were incubated with TNF- $\alpha$ at the doses of $0,9.8$, or $980 \mathrm{ng} / \mathrm{mL}$ in the incubation media for $60 \mathrm{~min}$.

The measurement of abundance of PEPCK $m R N A$, GK $m R N A$, GLUT1 mRNA, and GLUT2 mRNA. mRNA abundance of PEPCK $(n=10)$, GK $(n=5)$, GLUT1 $(n=10)$, and GLUT2 $(n=10)$ was measured using a Northern blot technique (27) as follows: Total RNA was isolated by a modified method of Chomczynski and Sacchi (28), then separated by electrophoresis on agarose-formaldehyde gel. The gel was blotted onto Nytran membrane (Schleicher \& Schull, Keene, NH, U.S.A.) and hybridized to $\left[{ }^{32} \mathrm{P}\right]-\mathrm{cDNA}$ riboprobes for $\mathrm{GK}$, PEPCK, GLUT1, and GLUT2. Hybridization was performed for $16-20 \mathrm{~h}$ at $65^{\circ} \mathrm{C}$ in modified Denhardt's solution. After hybridization, membranes were washed and exposed to Hyperfilm (Amersham, Arlington Heights, IL, U.S.A.) at $-70^{\circ} \mathrm{C}$ with an intensifying screen for $2 \mathrm{~h}$. The mRNA abundance of GK, GLUT1, GLUT2, and PEPCK in total RNA samples was measured by densitometry of autoradiographic bands using the
AMBIS Imaging System (AMBIS, San Diego, CA, U.S.A.). Signals were normalized for loading based on $28 \mathrm{~S}$ ribosomal RNA, and expressed as percentages of controls $(27,29)$. Riboprobes for PEPCK, GK, GLUT1, and GLUT2 were cGK.ZIA (2.36-kb insert) in pBluescript, 846-bp fragment of PC116 in pGEM-3Z, phGT-2 (1.8-kb insert) in pGEM-4Z, and pLGT (0.9-kb insert) in pGEM-4Z, respectively.

\section{RESULTS}

Effects of LPS on glucose production in hepatocytes. Glucose production in hepatocytes isolated from 10-d-old rats was $96 \pm 9(n=12), 105 \pm 8(n=12)$, and $92 \pm 7(n=12)$ $\mu \mathrm{mol} / 10^{6}$ cells after incubation with endotoxin at the dose of 0 , 0.01 , and $0.1 \mu \mathrm{g} / \mathrm{mL}$, respectively. There was no significant difference in glucose production among the groups.

Effects of TNF-a on gluconeogenesis in hepatocytes. Gluconeogenesis in hepatocytes isolated from 10-d-old rats was $98.2 \pm 8.2(n=12), 56.6 \pm 21.1(n=12), 48.3 \pm 6.6(n=$ $10), 25.0 \pm 7.8(n=12)$, and $1.1 \pm 2.3(n=12) \mu \mathrm{mol} / 10^{6}$ cells in groups 1 (noTNF $\alpha), 2$ (0.98TNF- $\alpha), 3$ (9.8TNF- $\alpha), 4$ (98TNF- $\alpha$ ), and 5 (980TNF- $\alpha$ ), respectively (Fig. 1). Gluconeogenesis was less $(p<0.05)$ in group $3(9.8 \mathrm{TNF}-\alpha)$ than in group 1 (noTNF $\alpha$ ), but was not different from that in group 2 $(0.98 \mathrm{TNF}-\alpha)$. Gluconeogenesis was less $(p<0.01)$ in group 4 $(98 \mathrm{TNF}-\alpha)$ than in group 1 (noTNF $\alpha$ ), but was not different from that in either group $2(0.98 \mathrm{TNF}-\alpha)$ or group 3 (9.8TNF$\alpha)$. Gluconeogenesis was less in group $5(980 \mathrm{TNF}-\alpha)$ than in both groups $2(0.98 \mathrm{TNF}-\alpha)$ and $3(9.8 \mathrm{TNF}-\alpha)(p<0.05)$ but was not different from that in group $4(98 \mathrm{TNF}-\alpha)$. Therefore, TNF- $\alpha$ decreased gluconeogenesis in a dose-dependent manner.

Gluconeogenesis in hepatocytes isolated from adult rats was $226 \pm 43(n=8), 185 \pm 68(n=8)$, and $217 \pm 44(n=8)$ $\mu \mathrm{mol} / 10^{6}$ cells at the doses of $0,9.8$, and $980 \mathrm{ng} / \mathrm{mL}$ of TNF- $\alpha$, respectively. There was no significant difference in gluconeogenesis among those three groups.

Glucose uptake. In hepatocytes isolated from 10-d-old rats, glucose uptake in group B $(9.8 \mathrm{TNF}-\alpha)$ was not different from that in group A (0TNF- $\alpha$ ) (Fig. 2). Glucose uptake was greater

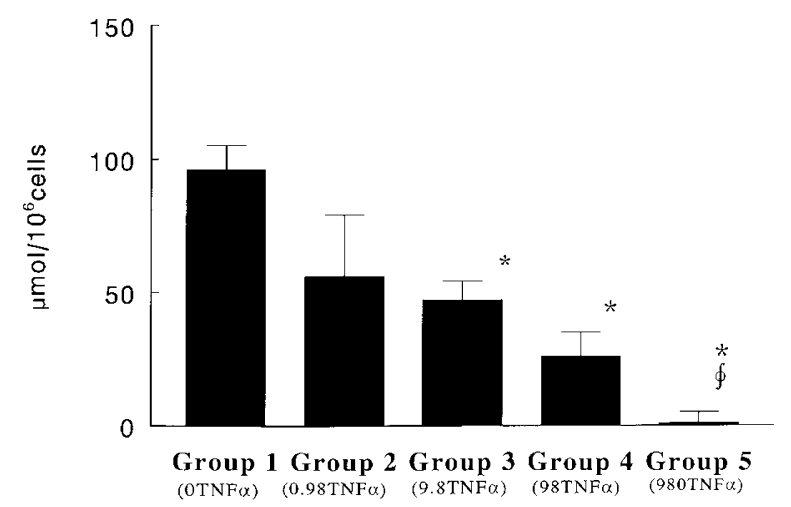

Figure 1. Gluconeogenesis in hepatocytes isolated from 10-d-old rats. Hepatocytes were incubated with TNF- $\alpha$ at different concentrations for $3 \mathrm{~h}$. Each value expressed by mean \pm SEM was obtained from 10 to 12 experiments. * $p<0.05$ compared with group $1(0 \mathrm{TNF}-\alpha)$. $\S p<0.05$ compared with groups 1 (0TNF- $\alpha), 2(0.98 \mathrm{TNF}-\alpha)$, and 3 (9.8TNF- $\alpha)$. 


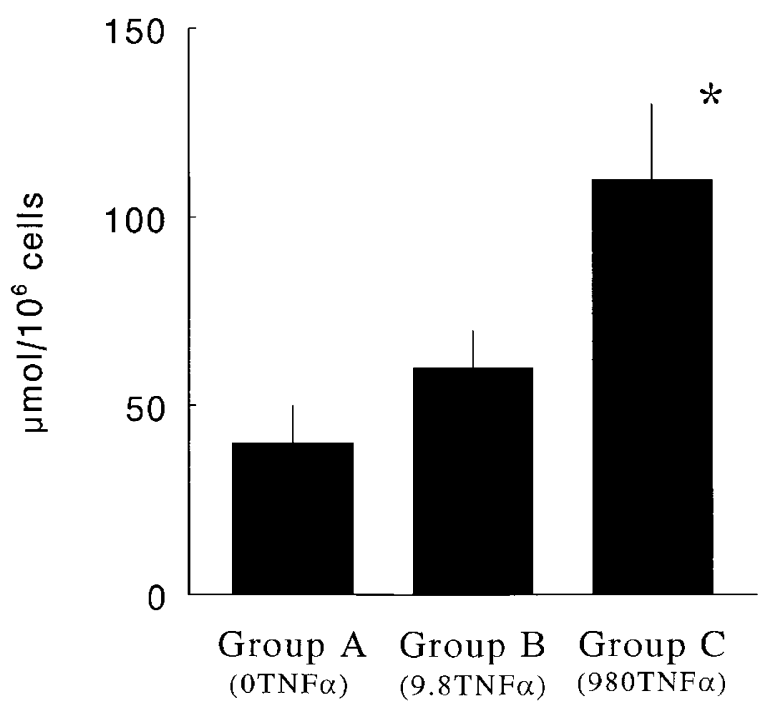

Figure 2. Glucose uptake in hepatocytes isolated from 10-d-old rats. Hepatocytes were incubated with TNF- $\alpha$ at different concentrations for $60 \mathrm{~min}$. Each value expressed by mean \pm SEM was obtained from five experiments. * $p<0.05$ compared with group A (0TNF- $\alpha)$ and group B $(9.8 \mathrm{TNF}-\alpha)$

$(p<0.05)$ in group $\mathrm{C}(980 \mathrm{TNF}-\alpha)$ than in both groups $\mathrm{A}$ (noTNF $\alpha$ ) and B (9.8TNF- $\alpha$ ). Thus, TNF- $\alpha$ seemed to increase the glucose uptake in a dose-dependent manner.

mRNA abundance in PEPCK, GK, GLUT1, and GLUT2. PEPCK mRNA abundance decreased in groups $3(9.8 \mathrm{TNF}-\alpha)$ $(p<0.05), 4(98 \mathrm{TNF}-\alpha)(p<0.05)$, and 5 (980TNF- $\alpha)(p<$ $0.01)$, when compared with group 1 (noTNF $\alpha)$. The decrease of PEPCK mRNA abundance seemed to be in a dosedependent manner (Fig. 3). However, PEPCK mRNA abundance was not significantly different among groups 2 $(0.98 \mathrm{TNF}-\alpha), 3(9.8 \mathrm{TNF}-\alpha), 4$ (98TNF- $\alpha$ ), and 5 (980TNF- $\alpha$ ). The decreased PEPCK mRNA abundance was correlated to the decreased gluconeogenesis $(r=0.972)$ (Fig. 4). GK mRNA abundance seemed to be increased in a dose-dependent manner (Fig. 5). GK mRNA abundance was greater $(p<0.05)$ in group $\mathrm{C}(980 \mathrm{TNF}-\alpha)$ than in group $\mathrm{A}(0 \mathrm{TNF}-\alpha)$. GLUT1

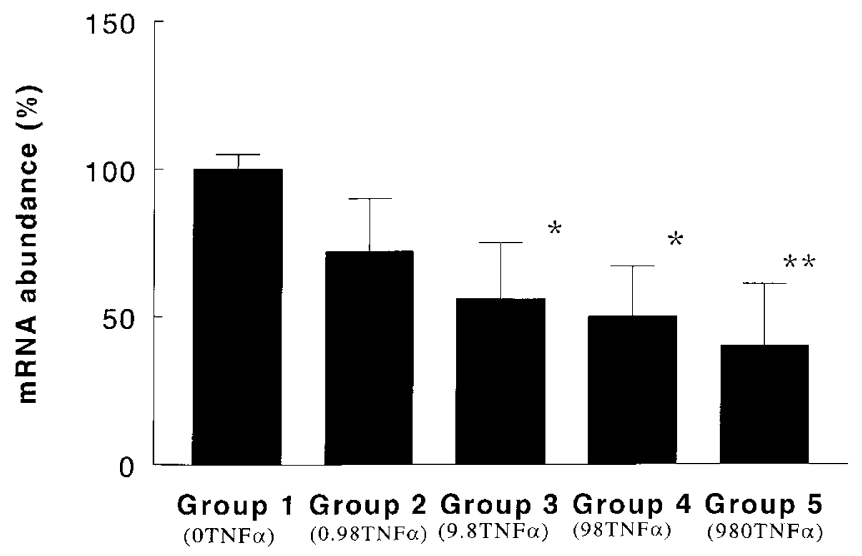

Figure 3. PEPCK mRNA abundance in hepatocytes after a 3-h incubation with TNF- $\alpha$. Signals were normalized for loading based on $28 \mathrm{~S}$ ribosomal RNA and expressed as percent of the mean value of group 1 (no TNF- $\alpha$ ). Each value was obtained from 10 experiments. Mean \pm SEM were calculated. $* p$ $<0.05$ compared with group $1(0 \mathrm{TNF}-\alpha)$ ) $\S p<0.01$ compared with group 1 $(0 \mathrm{TNF}-\alpha)$.

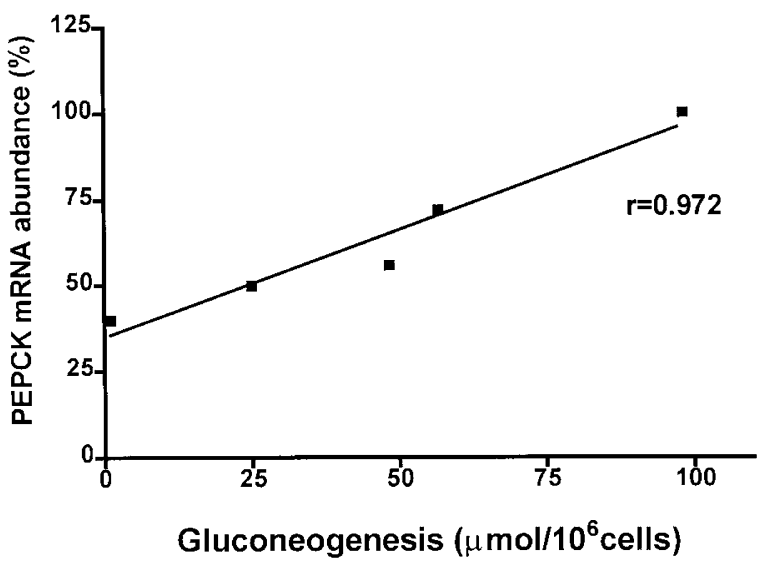

Figure 4. The correlation between the gluconeogenesis and PEPCK mRNA abundance. The decrease of mRNA abundance of PEPCK by TNF- $\alpha$ was correlated with the decrease of the gluconeogenesis $(r=0.972)$.

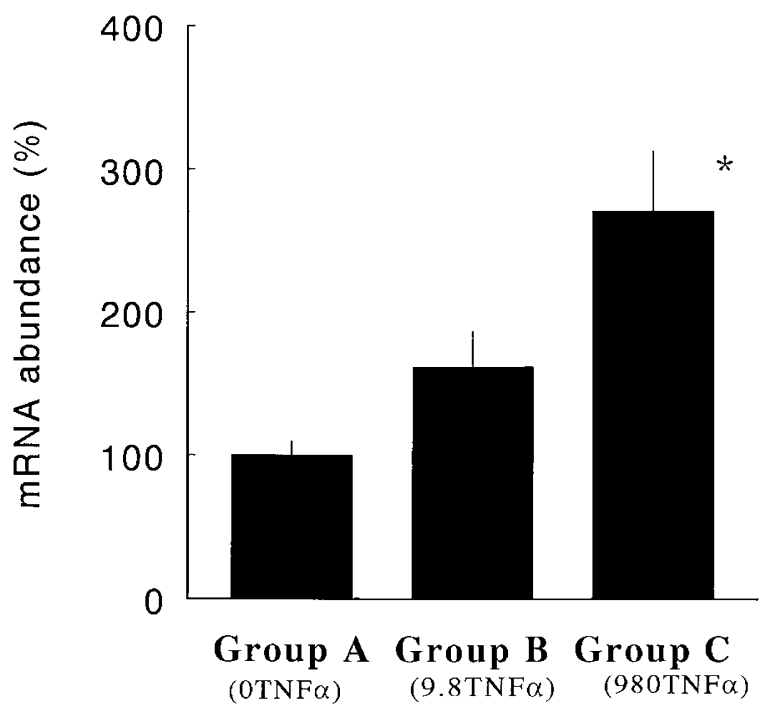

Figure 5. GK mRNA abundance in hepatocytes after a 3-h incubation with TNF- $\alpha$. Signals were normalized for loading based on $28 \mathrm{~S}$ ribosomal RNA and expressed as percent of the mean value of group 1 (noTNF $\alpha$ ). Each value was obtained from five experiments. Mean \pm SEM were calculated. ${ }^{*} p<0.05$ compared with group A $(0 \mathrm{TNF}-\alpha)$.

mRNA abundance was also increased in a dose-dependent manner (Fig. 6). GLUT1 mRNA abundance was greater in groups $4(98 \mathrm{TNF}-\alpha)(p<0.05)$ and $5(980 \mathrm{TNF}-\alpha)(p<0.01)$ than in group $1($ noTNF $\alpha)$. GLUT1 mRNA abundance was greater $(p<0.05)$ in group $5(980 \mathrm{TNF}-\alpha)$ than in groups 2 $(0.98 \mathrm{TNF}-\alpha)$ and $3(9.8 \mathrm{TNF}-\alpha)$. The increased glucose uptake was correlated with both the increased GK mRNA abundance $(r=0.988)$ and the increased GLUT1 mRNA abundance $(r=$ 0.997) (Fig. 7). GLUT2 mRNA abundance was decreased to $30-35 \%(p<0.05)$ in groups $2(0.98 \mathrm{TNF}-\alpha), 3(9.8 \mathrm{TNF}-\alpha), 4$ $(98 \mathrm{TNF}-\alpha)$, and 5 (980TNF- $\alpha$ ) when compared with group 1 $($ noTNF $\alpha$ ) (Fig. 8). There was no significant difference in GLUT2 mRNA abundance among groups $2(0.98 \mathrm{TNF}-\alpha), 3$ $(9.8 \mathrm{TNF}-\alpha), 4(98 \mathrm{TNF}-\alpha)$, and 5 (980TNF- $\alpha)$.

\section{DISCUSSION}

The present study demonstrated that LPS did not alter glucose production in hepatocytes isolated from 10-d-old rats 


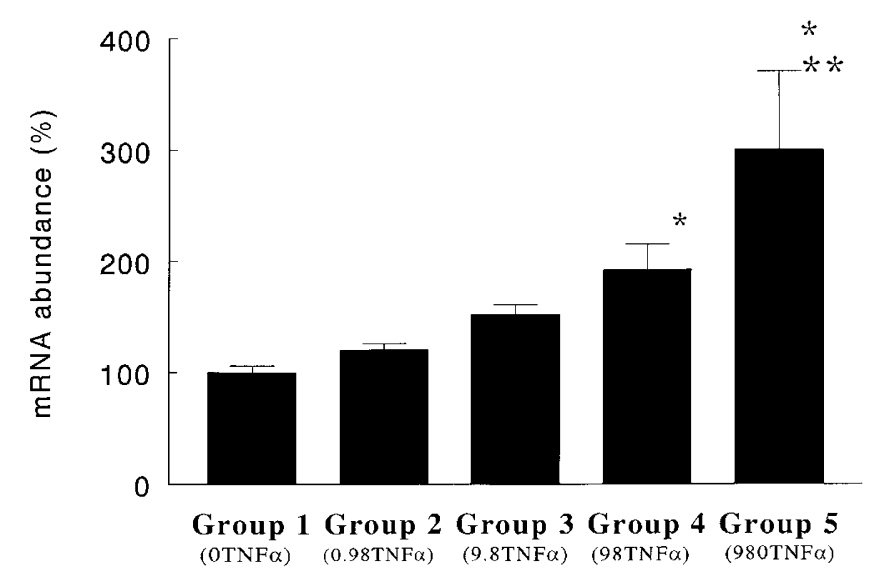

Figure 6. GLUT1 mRNA abundance in hepatocytes after a 3-h incubation with TNF- $\alpha$. Signals were normalized for loading based on $28 \mathrm{~S}$ ribosomal RNA and expressed as percent of the mean value of group 1 (noTNF $\alpha$ ). Each value was obtained from 10 experiments. Mean \pm SEM were calculated. $* p$ $<0.01$ compared with group $1(0 \mathrm{TNF}-\alpha)$. $\S p<0.05$ compared with groups $2(0.98 \mathrm{TNF}-\alpha)$ and $3(9.8 \mathrm{TNF}-\alpha)$.

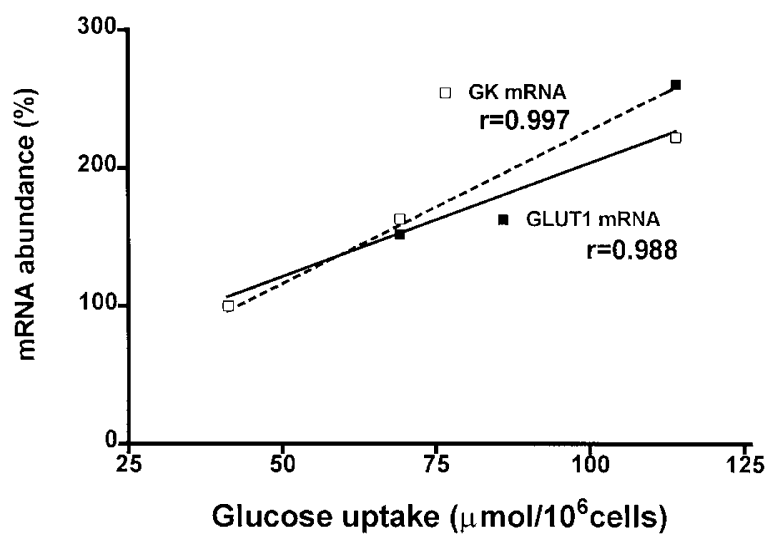

Figure 7. The correlation between glucose uptake and mRNA abundance of GK and GLUT1. The increase of mRNA abundance of GK and GLUT1 correlated with the increase of the glucose uptake $(r=0.988$ and 0.997 , respectively).

but TNF- $\alpha$ decreased gluconeogenesis in a dose-dependent manner. The lack of LPS effects on glucose production confirmed previous observations by other investigators (10) and ourselves that LPS by itself might not alter hepatocyte glucoregulation (11). In the present study, abundance of mRNA of PEPCK, a rate-limiting enzyme in gluconeogenesis, was decreased by TNF- $\alpha$ in a dose-dependent manner, and the decrease in gluconeogenesis was closely related to the decrease in PEPCK mRNA abundance $(r=0.972)$. Our previous study shows that the decrease in gluconeogenesis in 10-d-old rats is associated with the decrease in activity and mRNA abundance of PEPCK during endotoxic shock (5). The decreased PEPCK gene expression confirmed the decrease of gluconeogenesis. In our present study, TNF- $\alpha$ decreased GLUT2 mRNA abundance. Because GLUT1 transports glucose primarily into cells and GLUT2 transports glucose bidirectionally across cell membranes (18), GLUT2 plays an important role in glucose release from hepatocytes. Therefore, a decrease in GLUT2 mRNA abundance might be expected to correlate with the decrease in gluconeogenesis. In the present study, however, the

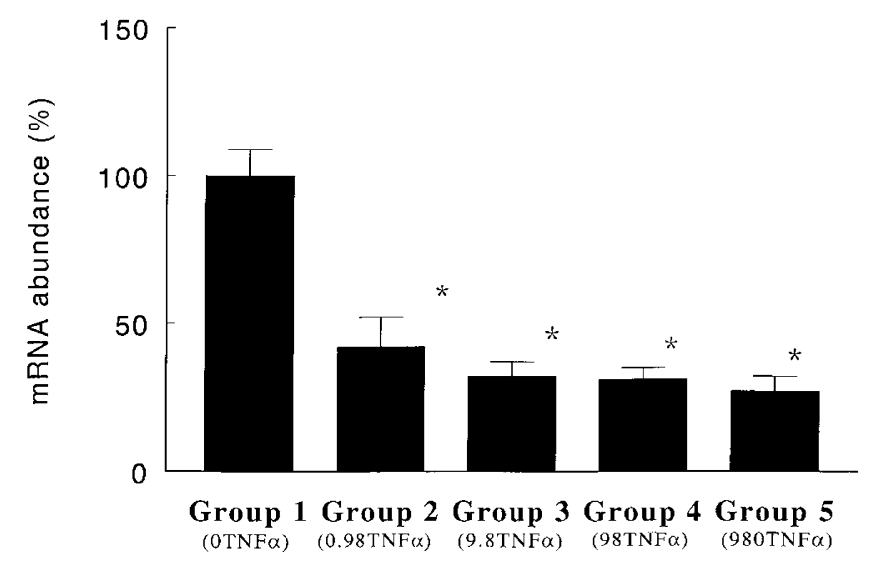

Figure 8. GLUT2 mRNA abundance in hepatocytes after a 3-h incubation with TNF- $\alpha$. Signals were normalized for loading based on $28 \mathrm{~S}$ ribosomal RNA and expressed as percent of the mean value of group 1 (noTNF $\alpha$ ). Each value was obtained from 10 experiments. Mean \pm SEM were calculated. ${ }^{*} p$ $<0.05$ compared with group 1 .

decrease in GLUT2 mRNA abundance did not correlate with the decrease in gluconeogenesis. These results suggested that gluconeogenesis might not correlate with GLUT2 concentration, but might correlate with altered GLUT2 function $\left(\mathrm{K}_{\mathrm{m}}\right)$.

TNF- $\alpha$ increased glucose uptake and GLUT1 mRNA abundance of the isolated hepatocytes in a dose-dependent manner. There was a good correlation $(r=0.997)$ between the increase of glucose uptake and the increase of GLUT1 mRNA abundance. Other investigators have shown that increase of noninsulin-mediated glucose uptake is associated with increase of GLUT1 gene expression in muscles during septic shock (20). Our previous study also showed that TNF- $\alpha$ increases glucose uptake and GLUT1 gene expression in the liver and fatty tissues of 10-d-old rats (16). Furthermore, TNF- $\alpha$ increases glucose uptake and GLUT1 gene expression in 3T3 cells (30). Therefore, the good correlation $(r=0.997)$ between the increase of glucose uptake and the increase of GLUT1 mRNA abundance suggested that GLUT might play an important role in the increase of glucose uptake. Because glucose uptake is assessed by the amount of phosphorylated 2-deoxy-glucose (26), the increased glucose uptake indicates the increased glucose phosphorylation, the first step of glycolysis. In the present study, abundance of mRNA of glucokinase, one of hexokinases, was increased in a dose-dependent manner, which correlated with the increase of glucose uptake $(r=0.997)$. These results suggested that TNF- $\alpha$ increased glycolysis in isolated hepatocytes. In the present study, there was a close relationship $(r=-0.988)$ between the increase of glucose uptake and the decrease of gluconeogenesis (Fig. 9). Glycolysis and gluconeogenesis are shown to be reciprocally regulated until a futile cycle is developed (31).

The present study showed that TNF- $\alpha$ did not alter gluconeogenesis in hepatocytes isolated from adult rats, confirming the findings of other investigators (17). Hill and McCallum (6) concluded from their in vivo studies that TNF- $\alpha$ was a transcriptional regulator of PEPCK and suppressed PEPCK function. However, the present study suggested that decreased PEPCK gene expression might not be caused by direct effects 


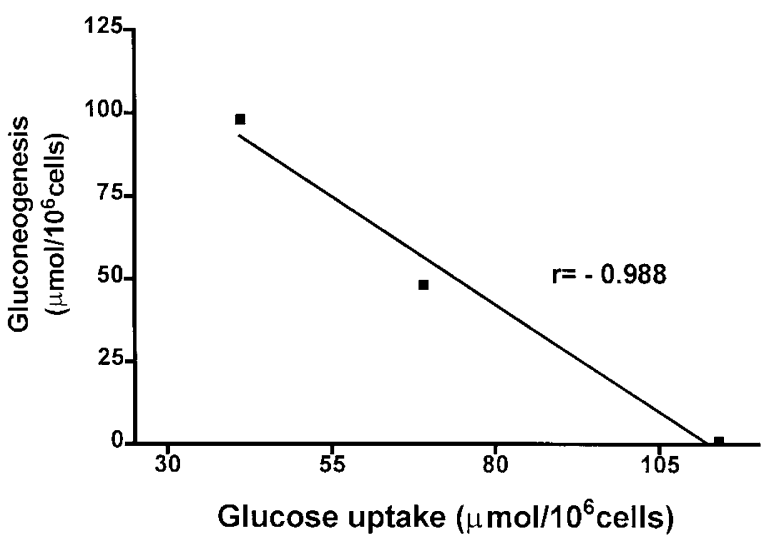

Figure 9. The correlation between the gluconeogenesis and the glucose uptake. The decrease of the gluconeogenesis by TNF- $\alpha$ was correlated with the increase of the glucose uptake $(n=-0.988)$.

of TNF- $\alpha$. From the present study, we speculated the mechanism of the lack of TNF- $\alpha$ effects on gluconeogenesis in hepatocytes isolated from adult rats as follows: GLUT2 is the predominant glucose transporter in the liver of adult rats (18, 19). Therefore, although TNF- $\alpha$ increased GLUT1-mediated glucose uptake and decreased GLUT2 gene expression, the existing GLUT2 continued to shuttle enough glucose. Thus, TNF- $\alpha$ did not alter gluconeogenesis. However, neither glucose transporter proteins nor their functions $\left(\mathrm{K}_{\mathrm{m}}\right)$ were measured in the present study. The role of glucose transporters in TNF- $\alpha$ effects on gluconeogenesis needs further investigations.

The newborn often develop hypoglycemia without hyperinsulinemia during septic shock $(32,33)$. The present study showed that TNF- $\alpha$ by itself inhibited hepatocyte gluconeogenesis in the newborn rats but not the adult rats. Our results indicate that the propensity to hypoglycemia during septic shock in the newborn may be related to TNF- $\alpha$-induced decrease in gluconeogenesis. Blood glucose concentration can be maintained by dextrose infusion. However, dextrose may suppress gluconeogenesis. Because TNF- $\alpha$ effects on gluconeogenesis seem to be related to GLUT1 predominance, a method to attenuate GLUT1-mediated glucose transport may be useful for the treatment of hypoglycemia during septic shock in the newborn

\section{REFERENCES}

1. Zeller WP, Gotgo M, Witek-Janusek L, Hurley RM 1991 Mortality, tempora substrate and insulin responses to endotoxic shock in zero, ten, and twenty-eight day old rats. Surg Gynecol Obstet 173:375-383

2. Witek-Janusek L 1988 Pituitary-adrenal response to bacterial endotoxin in developing rats. Am J Physiol 255:E525-E530

3. Filkins JP 1974 Phases of glucose dyshomeostasis in endotoxicosis. Circ Shock $5: 347-355$

4. Ebata T, Kuttner RE, Apantaku FO, Shumer W 1983 Effect of a new synthetic complement inhibitor on hepatic glycolytic intermediates in septic rats. Adv Shock Res 9:275-282
5. Goto M, Zeller W, Lichtenberg RC 1994 Decreased gluconeogenesis and increased glucose disposal without hyperinsulinemia in 10 day old rats with endotoxic shock. Metabolism 43:1248-1254

6. Hill MR, McCallum RE 1992 Identification of tumor necrosis factor as a transcriptional regulator of the phosphoenolpyruvate carboxykinase gene following endotoxin treatment of mice. Infect Immun 60:4040-4050

7. Stith RD, McCallum RE 1988 Failure of glucagon to induce hepatic phosphoenolpyruvate carboxykinase in endotoxic shock. Circ Shock 26:267-272

8. Postic C, Leturque A, Printz RL, Maulard P, Loizeau M, Granner DK, Girard J 1995 Development and regulation of glucose transporter and hexokinase expression in rat. Am J Physiol 266:E548-E559

9. Yelich MR, Filkins JP 1982 Insulin hypersecretion and potentiation of endotoxin shock in the rat. Circ Shock 9:590-603

10. West MA, Billiar TR, Mazuski JE, Curran RJ, Cerra FB, Simmons RL 1988 Endotoxin modulation of hepatocyte secretory and cellular protein synthesis is mediated by Kupffer cells. Arch Surg 123:1400-1405

11. Goto M, Zeller WP, Picken M, Goto MP, Hurley RM 1993 Lipopolysaccharide alters suckling rat liver glycogenolysis. Circ Shock 40:53-60

12. Girardin EP, Berner ME, Grau GE, Suter S, Lacourt G, Paunier L 1990 Serum tumor necrosis factor in newborns at risk for infections. Eur J Pediatr 149:645-649

13. Tracey KJ, Beutler B, Lowry SF, Merryweather J, Wolfe S, Milsark IW, Hariri RI, Fahey TJ, Zentella A, Albert ID, Shires GT, Cerami A 1986 Shock and tissue injury induced by recombinant human cachectin. Science 234:470-474

14. Metzger S, Begleibter N, Barash V, Drize O, Peretz T, Shiloni E, Chajek-Shaul T 1997 Tumor necrosis factor inhibits the transcriptional rate of glucose-6-phosphatase in vivo and in vitro. Metabolism 46:579-583

15. Yasmineh WG, Theologides A 1992 Effects of tumor necrosis factor on enzymes of gluconeogenesis in the rats. Proc Soc Exp Biol Med 199:97-103

16. Battelino T, Goto M, Krzisnik C, Zeller WP 1999 Tumor necrosis factor $\alpha$ alters glucose metabolism in suckling rats. J Lab Clin Med 133:583-589

17. Rofe AM, Conyers RAJ, Bais R, Gamble JF, Vadas MA 1987 The effects of recombinant tumor necrosis factor (cachectin) on metabolism in isolated rat adipocyte, hepatocyte and muscle preparation. Biochem J 247:789-792

18. Gould GW, Seatter MJ 1997 Introduction to the facilitative glucose transporter family. In: Gould GW (ed) Facilitative Glucose Transporters. Chapman and Hall, New York, pp 1-38

19. Santalucia T, Camps M, Castello, Munoz P, Nuel A, Testar X, Palacin TM, Zorzano A 1992 Developmental regulation of GLUT-1 (erythroid/Hep G2) and GLUT-4 (muscle/fat) glucose transporter expression in rat heart, skeletal muscle, and brown adipose tissue. Endocrinology 130:837-846

20. Vary TC, Drnevich D, Jurasinski C, Brennan Jr WA 1995 Mechanisms regulating skeletal muscle glucose metabolism in sepsis. Shock 3:403-410

21. Lang CH, Dobrescu C 1991 Gram-negative infection increases noninsulin-mediated glucose disposal. Endocrinology 128:645-653

22. Dahn MS, Hsu CJ, Lange P, Jefferson LS 1994 Effects of tumor necrosis factor- $\alpha$ on glucose and albumin production in primary cultures of rat hepatocytes. Metabolism 43:476-480

23. Kraegen EW, Sowden JA, Halstead MB, Clark PW, Rodnick KJ, Chisholm DJ, James DE 1993 Glucose transporters and in vivo glucose uptake in skeletal and cardiac muscle: fasting, insulin stimulation and immunoisolation studies of GLUT1 and GLUT4. Biochem J 295:287-293

24. Tordjman KM, Leingang KA, Mueckler M 1990 Differential regulation of the HepG2 and adipocyte/muscle glucose transporters in 3T3L1 adipocytes. Biochem J 271:201207

25. Harbrecht BG, Billiar TR, Curran RD 1992 Experimental models for studying the interaction of Kupffer cells and hepatocytes. In: Billiar TR, Curran RD (eds) Hepatocyte and Kupffer Cell Interactions. CRC Press, Ann Arbor, MI, pp 55-70

26. Chen V, McDough KH, Spitzer JJ 1985 Effects of insulin on glucose metabolism in isolated heart myocytes from adult rats. Biochim Biophys Acta 846:398-404

27. Zeller WP, The SM, Sweet M, Goto M, Gottsckalk ME, Hurley RM, Filkins JP, Hofmann C 1991 Altered glucose transporter mRNA abundance in a rat model of endotoxic shock. Biochem Biophys Res Commun 176:535-540

28. Chomczynski P, Sacchi N 1987 Single step method of RNA isolation by acid guanidium thiocyanate-phenol-chloroform extraction. Ann Biochem 162:156-159

29. deLeevw WJF, Slagoom PE, Vijg J 1989 Quantitative comparison of mRNA levels in mammalian tissues: 28S ribosomal RNA level as an accurate internal control. Nucleic Acids Res 17:10137-10138

30. Cornelius P, Marlowe M, Pekala PH 1990 Regulation of glucose transport by tumor necrosis factor- $\alpha$ in cultured murine 3T3-L1 fibroblasts. J Trauma 30:S15-S20

31. Pilkis SJ, Granner DK 1992 Molecular physiology of the regulation of hepatic gluconeogenesis and glycolysis. Ann Rev Physiol 54:885-909

32. Yeung CY, Lee VWY, Yeung MB 1973 Glucose disappearance rate in neonatal infection. J Pediatr 82:486-489

33. Leake RD, Fisher Jr RH, Oh W 1981 Rapid glucose disappearance in infants with infection. Clin Pediatr 20:397-401 